\section{Subklinisk hypotyreose i svangerskapet}

Barns kognitive evner blir ikke bedre av at mor får levotyroksin for subklinisk hypotyreose eller hypertyroksinemi under svangerskapet, viser ny studie.

I en amerikansk studie ble gravide kvinner med påvist subklinisk hypotyreose og hypertyroksinemi ved screening innen 20 . svangerskapsuke randomisert til behandling med levotyroksin eller placebo (1). Kvinnenes stoffskifte ble kontrollert hver måned gjennom hele svangerskapet, og barna ble fulgt frem til femårsalderen.

Totalt 677 kvinner med subklinisk hypotyreose, definert som nivå av tyreoideastimulerende hormon $(\mathrm{TSH}) \geq 4 \mathrm{mU} / \mathrm{l}$, og normalt nivå av fritt tyroksin (T4), og 526 kvinner med hypertyroksinemi, definert som normalt TSH-nivå og T4-nivå lavere enn $0,86 \mathrm{ng} / \mathrm{dl}$ (tilsvarende $11 \mathrm{pmol} / \mathrm{l}$ ), ble inkludert i studien. Median IQ-skår hos barn av mødre behandlet med levotyroksin på grunn av subklinisk hypotyreose, var 97 (95\% KI 94-99) versus 94 (95\% KI 92-96) i placebogruppen $(\mathrm{p}=0,71)$. Blant mødre med hypertyroksinemi var median IQ-skår hos barna henholdsvis 94 (95\% KI 91-95) og 91 (95\% KI 89-93) i hver gruppe $(p=0,30)$. Det var ingen forskjell i nevrokognitiv utvikling eller svangerskapskomplikasjoner mellom levotyroksingruppen og placebogruppen.

- Dette er den fjerde og største randomiserte studien om behandling av subklinisk hypotyreose i svangerskapet, sier Bjørn Gunnar Nedrebø, klinikkoverlege ved Medisinsk klinikk, Haugesund sjukehus, og førsteamanuensis ved Universitetet i Bergen. - Vi kan nå være rimelig sikre på at levotyroksinbehandling for subklinisk hypotyreose fra begynnelsen av andre trimester ikke reduserer risikoen for svangerskapskomplikasjoner eller bedrer psykomotorisk utvikling hos barna.

- Vi mangler fortsatt gode studier på be-handlingsoppstart med levotyroksin hos kvinner med subklinisk hypotyreose før svangerskapsuke $6-10$, som er en sårbar periode for fosteret. Subklinisk hypotyreose diagnostisert i første trimester hos kvinner med antistoffer mot tyreoperoksidase (antiTPO) bør derfor fortsatt vurderes for behandling, mener Nedrebø.

\section{Kari Tveito}

Tidsskriftet

\footnotetext{
Litteratur

1. Casey BM, Thom EA, Peaceman AM et al. Treatment of subclinical hypothyroidism or hypothyroxinemia in pregnancy. N Engl J Med 017; 376: 815-25.
}

\title{
De eldste kineserne er blitt skrøpeligere
}

\author{
Dødeligheten blant kinesere over 80 år har gått ned fra 1998 til 2008, \\ men den fysiske og mentale prestasjonsevnen har falt.
}

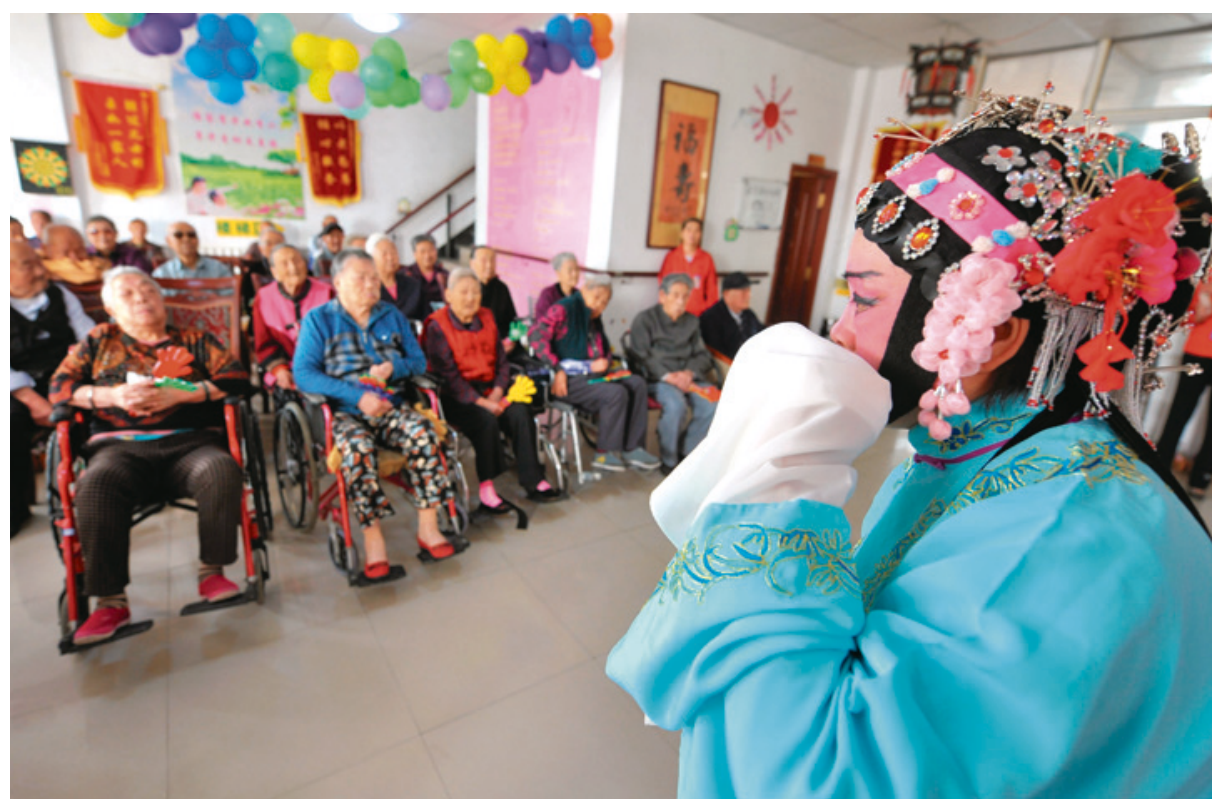

En tradisjonell kinesisk operaforestilling på et sykehjem for eldre i Qingdao, Øst-Kina. Foto: Sipa USA/NTB scanpix

Antall mennesker over 80 år øker raskt i mange land, også i Kina. I en ny studie har man sett på utviklingen i helsen til eldre kinesere ved å sammenligne kohorter av personer som var henholdsvis 80-89 år, 90-99 år og 100-105 år i 1998 og tilsvarende kohorter i 2008. Totalt omfattet studien nesten 20000 eldre mennesker (1).

Dødeligheten gikk ned for alle alderskategoriene, men forskjellene var ganske beskjedne og statistisk signifikante bare for dem over 100 år. For eksempel sank den årlige dødsraten for menn i alderen 90-99 år fra $27,1 \%$ i 1998 til $25,6 \%$ i 2008 . For alle aldersgrupper var evnen til å mestre dagliglivets aktiviteter signifikant bedre i 2008 sammenlignet med samme aldersgrupper $\mathrm{i}$ 1998. Likevel presterte de eldste signifikant dårligere på fysiske tester, slik som å reise seg fra en stol eller å plukke opp en gjenstand fra gulvet. Resultatene av testen Mini Mental Status var også dårligere i 2008 enn for jevnaldrende i 1998. Også selvrapportert livskvalitet og egenvurdert helsetilstand var dårligere.
Forfatterne påpeker at resultatene ligner på resultatene i en tilsvarende dansk studie. De mener at årsaken til den nedadgående trenden i helse for de eldste kan være at det i 2008 levde flere skrøpelige personer som tidligere ville ha dødd i yngre alder. Disse har overlevd som følge av medisinske og samfunnsmessige fremskritt - dette omtaler de som «kostnaden ved suksess». At dagliglivets aktiviteter mestres bedre forklarer de med økt tilgang på hjelpemidler i hjemmet, relatert til økt levestandard i Kina.

\section{Kristoffer Brodwall \\ kristoffer.brodwall@gmail.com \\ Barne- og ungdomsklinikken}

Haukeland universitetssykehus

\section{Litteratur \\ 1. Zeng Y, Feng Q, Hesketh T et al. Survival, disabili- ties in activities of daily living, and physical and cognitive functioning among the oldest-old in China: a cohort study. Lancet 2017. E-publisert 9. mars 2017.}

